\title{
Big buzz as cicadas arrive after 17-year gap
}

\section{Laura Nelson, Washington}

The emergence of periodical cicadas across the eastern United States, after 17 years underground, is offering scientists an infrequent opportunity to study the insects' interaction with the environment.

Trillions of the Magicicada will appear this month to fornicate furiously for about six weeks and then die, while a rather smaller number of entomologists, evolutionary biologists and ecologists grab the chance to study the phenomenon. Newly hatched cicadas will then migrate underground and feed on tree roots for another 17 years.

The regular timing of the emergence intrigues evolutionary biologists. Other researchers will study how human behaviour affects the cicada population, and how the intense insect swarm interacts with its habitat.

"This is a 17-year experiment," says Keith Clay, a biologist at Indiana University, Bloomington, and one of about a dozen senior US scientists whose professional lives are devoted to the study of periodical cicadas. For them, this spring's buzz is the culmination of years of preparation.

Indiana has wide swathes of deciduous forest and is a "vast natural laboratory", says Clay. To investigate the impact of cicadas on trees, he has created a chessboard of patches of plastic sheeting at a military base in Crane, Indiana, to compare the condition of trees before and after the insects emerge from the ground.

Despite the fears of some, who say that massive urbanization on the eastern seaboard will disrupt the cicadas' cycle, most researchers expectabumper crop of the insects this year. Reforestation of disused farmland in the region, together with suburban sprawl,

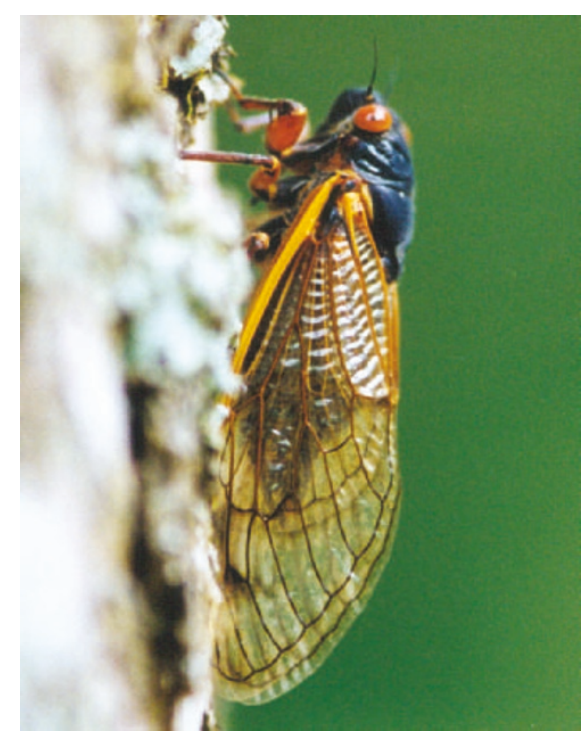

Tree for all: trillions of cicadas will emerge to lay their eggs over the next six weeks.

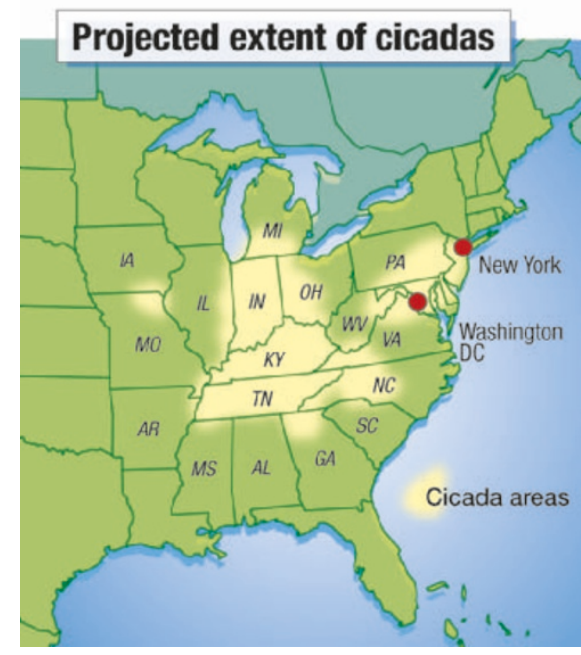

should facilitate their breeding.

"We have more forest now than at any time in the past 100 years," says John Odland, a geographer at Indiana University. Cicadas favour young trees that will last for many generations, as well as the warm sunlit areas around the edges of forests. Such conditions are common in the suburbs. Researchers say that in some places there will be more than 370 noisy, colourful insects for each square metre. The scene will be "like a science fiction movie", enthuses May Berenbaum, who is an entomologist at the University of Illinois at Urbana-Champaign.

James Speer, a biogeographer at Indiana State University, Terre Haute, is studying the cicadas' impact on forestry by analysing treering formation to check growth rates in cicadaintensive regions. Growth is hardest hit just before emergence, he explains, when cidadas are guzzling roots in preparation for their six weeks in the sun. "After emergence, tree growth rate increases again," he says.

But perhaps the most interesting question about the creatures is why they spend 17 years underground, a cycle that has been recorded since the mid-nineteenth century.

Biologists think it is no coincidence that cicadas have evolved to reappear with periods that are large prime numbers. If the life cycle of a breed was 12 years, they speculate, it would interbreed frequently with others that had life cycles of 2, 3, 4 or 6 years. "The prime number prevents mating between two broods and hybridization," says Christine Simon, an evolutionary biologist at the University of Connecticut. There are 13-year and 17-year broods, and these can only meet up every 221 years, giving them ample time to forge their unmistakable identities.

t www.cicadamania.com

\section{Britain plans laws to restrain animal-rights activists}

\section{Jim Giles, London}

The British government has committed itself to legislation that will specifically target crimes committed by animal-rights activists. But early indications are that the law will fail to satisfy research lobby groups.

Calls for such legislation have intensified following a decision in January by the University of Cambridge to scrap ambitious plans for a primate research centre. The plan was abandoned in part because of the extra security costs of protecting the facility and its staff against attacks by activist groups, some of which have gained notoriety for their violent attacks on people and property associated with animal research (see Nature 428, 882; 2004).
New laws designed to curb such protests are now being developed, science minister David Sainsbury told the House of Commons Science and Technology Committee on 12 May. Sainsbury revealed little about the legislation - but he did say that it will be tacked on to another bill.

But groups such as the Research Defence Society, a lobby group that defends animal testing, say that a bill is needed that is dedicated fully to animal research, comparable to the Football (Disorder) Act 2000, which was introduced to tackle violence at soccer matches. Lobbyists say this would ensure that tough penalties can be imposed for crimes committed in the name of animal rights. "The government has added bits to bills before and it hasn't solved the problem," says Mark Matfield, director of the society.

Sainsbury did earn praise from Matfield and others for confirming that the legislation will address one particular cause for concern - protests outside the homes of staff of companies with links to animal research.

The Home Office, which will draft the new legislation, says it is too early to say what form these restrictions will take. A spokeswoman says that a previous set of laws designed to tackle animal-rights extremists was implemented in January, and needs to be monitored before further measures can be finalized. 